\title{
Health insurance sector in India: an analysis of its performance
}

\author{
Madan Mohan Dutta \\ Department of Management, JD Birla Institute, Kolkata, India
}

\begin{abstract}
Purpose - Health insurance is one of the major contributors of growth of general insurance industry in India. It alone accounts for around $29 \%$ of total general insurance premium income earned in India. The growth of this sector is important from the perspective of overall growth of general insurance Industry. At the same time, problems in this sector are also many which are affecting its performance.

Design/methodology/approach - The paper provides an understanding on performance of health insurance sector in India. This study attempts to find out how much claims and commission and management expenses it has to incur to earn certain amount of premium. Methodology used for the study is regression analysis to establish relationship between dependent variable (Profit/Loss) and independent variable (Health Insurance Premium earned).

Findings - Findings of the study indicate that there is significant relationship between earned premium and underwriting loss. There has been increase of premium earnings which instead of increasing profit for the sector in fact has increased underwriting loss over the years. The earnings of the sector is growing at compounded annual growth rate of $27 \%$ still it is unable to earn underwriting profit.
\end{abstract}

Originality/value - This study is self-driven based on secondary data obtained from insurance regulatory and development authority site.

Keywords Health insurance premium, Claims, Commission, Management expenses,

Insurance regulatory and development authority, Underwriting loss, Compound annual growth rate

Paper type Research paper

\section{Introduction}

\subsection{Meaning of insurance}

Insurance is a contract between two parties where by one party agrees to undertake the risk of the other in exchange for consideration known as premium and promises to indemnify the party on happening of an uncertain event. The great advantage of insurance is that it spreads the risk of a few people over a large group of people exposed to risk of similar type.

Insurance has been identified as a sunrise sector by the financial planners of India. The insurance industry has lot of potential to grow, penetrate and service the masses of India. Insurance is all about protection. An insured needs two types of protection life and non-life. General insurance industry deals with non-life protection of the insured of which health insurance is a part.

(C) Madan Mohan Dutta. Published in Vilakshan - XIMB Journal of Management. Published by Emerald Publishing Limited. This article is published under the Creative Commons Attribution (CC BY 4.0) licence. Anyone may reproduce, distribute, translate and create derivative works of this article (for both commercial and non-commercial purposes), subject to full attribution to the original publication and authors. The full terms of this licence maybe seen at http://creativecommons.org/ licences/by/4.0/legalcode

Received 9 July 2020 Revised 10 August 2020 27 August 2020 Accepted 1 September 2020 
$\mathrm{XJM}$

$17,1 / 2$

98

\subsection{Meaning of health insurance}

Health insurance is a part of general insurance which contributes about $29 \%$ of premium amongst all other sectors of general insurance. But problems in this sector are many which is the driving force behind this study. This study will help the insurance companies to understand their performance and the quantum of losses that this sector is making over the years.

A plan that covers or shares the expenses associated with health care can be described as health insurance. These plans fall into commercial health insurance, which is provided by government, private and stand-alone health insurance companies.

Health insurance in India typically pays for only inpatient hospitalization and for treatment at hospitals in India. Outpatient services are not payable under health policies in India. The first health policy in India was Mediclaim Policy. In 2000, the Government of India liberalized insurance and allowed private players into the insurance sector. The advent of private insurers in India saw the introduction of many innovative products like family floater plans, critical illness plans, hospital cash and top-up policies.

Health insurance in India is an emerging insurance sector after life and automobile insurance sector. Rise in middle class, higher hospitalization cost, expensive health care, digitization and increase in awareness level are some important drivers for the growth of health insurance market in India.

Lifestyle diseases are on the rise. A sedentary lifestyle has pervaded our being. There is lower physical labour today than earlier and there is no reason why this would not be the trend going forward. The implication is the advent of lifestyle chronic diseases such as cardiac problems and diabetes.

In the context of the Indian health insurance industry, one could look at it both ways. Mired by low penetration and negative consumer perception about its utility are affecting the prospect of this industry. The flipside though is that we have hardly scratched the surface of the opportunity that lies in the future. It is as if the glass is half full. Much remains to be conquered and even more remains to be accomplished.

Health insurance companies needs to be optimistic and have courage to bring in innovation in the areas of product, services and distribution system. Bring it to the fold as the safety net that smartly covers and craft a health insurance plan befitting the need of the customers.

\subsection{Background of health insurance sector in India}

India's tryst with health insurance programme goes back to the late 1940s and early 1950s when the civil servants (Central Government Health Scheme) and formal sector workers (Employees' State Insurance Scheme) were enrolled into a contributory but heavily subsidized health insurance programmes. As a consequence of liberalization of the economy since the early 1990s, the government opened up private sector (including health insurance) in 1999. This development threw open the possibility for higher income groups to access quality care from private tertiary care facilities. However, India in the past five years (since 2007) has witnessed a plethora of new initiatives, both by the central government and a host of state governments also entering the bandwagon of health insurance. One of the reasons for initiating such programs may be traced to the commitment of the governments in India to scale up public spending in health care.

\subsection{The need for health insurance in India}

1.4.1 Lifestyles have changed. Indians today suffer from high levels of stress. Long hours at work, little exercise, disregard for a healthy balanced diet and a consequent dependence on 
junk food have weakened our immune systems and put us at an increased risk of contracting illnesses.

1.4.2 Rare non-communicable diseases are now common. Obesity, high blood pressure, strokes and heart attacks, which were earlier considered rare, now affect an increasing number of urban Indians.

1.4.3 Medical care is unbelievably expensive. Medical breakthroughs have resulted in cures for dreaded diseases. These cures however are available only to a select few. This is because of high operating and treatment expenses.

1.4.4 Indirect costs add to the financial burden. Indirect sources of expense like travel, boarding and lodging, and even temporary loss of income account for as much as $35 \%$ of the overall cost of treatment. These facts are overlooked when planning for medical expenses.

1.4.5 Incomplete financial planning. Most of us have insured our home, vehicle, child's education and even our retirement years. Ironically however we have not insured our health. We ignore the fact that illnesses strike without warning and seriously impact our finances and eat into our savings in the absence of a good health insurance or medical insurance plan.

\subsection{Classification of health insurance plans in India}

Health insurance plans in India today can be broadly classified into the following categories:

1.5.1 Hospitalization. Hospitalization plans are indemnity plans that pay cost of hospitalization and medical costs of the insured subject to the sum insured. There is another type of hospitalization policy called a top-up policy. Top-up policies have a high deductible typically set a level of existing cover.

1.5.2 Family floater health insurance. Family health insurance plan covers entire family in one health insurance plan. It works under assumption that not all member of a family will suffer from illness in one time.

1.5.3 Pre-existing disease cover plans. It offers covers against disease that policyholder had before buying health policy. Pre-existing disease cover plans offers cover against preexisting disease, e.g. diabetes, kidney failure and many more. After waiting for two to four years, it gives covers to the insured.

1.5.4 Senior citizen health insurance. This type of health insurance plan is for older people in the family. It provides covers and protection from health issues during old age.

1.5.5 Maternity Health insurance. Maternity health insurance ensures coverage for maternity and other additional expenses.

1.5.6 Hospital daily cash benefit plans. Daily cash benefits are a defined benefit policy that pays a defined sum of money for every day of hospitalization.

1.5.7 Critical illness plans. These are benefit-based policies which pay a lump sum amount on certain critical illnesses, e.g. heart attack, cancer and stroke.

1.5.8 Disease-specific special plans. Some companies offer specially designed diseasespecific plans such as Dengue Care and Corona Kavach policy.

\subsection{Strength, weakness, opportunity and threat analysis of health insurance sector (SWOT analysis)}

The strengths, weaknesses, opportunities and threats (SWOT) is a study undertaken to identify internal strengths and weaknesses as well as external opportunities and threats of the health insurance sector.

1.6.1 Strengths. The growth trend of the health insurance sector is likely to be high due to rise in per capita income and emerging middle-income group in India. New products are being launched in this sector by different insurance companies which will help to satisfy 
$\mathrm{XJM}$

$17,1 / 2$

customers need. Customers will be hugely benefited when cash less facility will be provided to all across the country by all the insurance companies.

1.6.2 Weaknesses. The financial condition of this sector is weak due to low investment in this sector. The public sector insurance companies are still dominating this industry due to their greater infrastructure facilities. This sector is prone to high claim ratio and many false claims are also made.

1.6.3 Opportunities. The possibility of future growth of this sector is high, as penetration in the rural sector is low. The improvement of technology and the use of internet facility are helping this sector to grow in magnitude and move towards environment-friendly paperless regime.

1.6.4 Threats. The biggest threat of this sector lies in the change in the government regulations. The profitability of this sector is affected due to increasing expenses and claims. The economic slowdown and recession in the economy can affect growth of this sector adversely. The increasing losses and need for insurance might reach a point of no return where insurance companies may be compelled to decline an insurance policy.

\subsection{Political economic socio cultural and technological analysis of health insurance sector (PEST analysis)}

This analysis describes a framework of macro-environmental factors used as strategic tool for understanding business position, growth potential and direction for operations.

1.7.1 Political factors. Service tax on premium on insurance policies is being increased by the government for past few years during budget. Government monopoly in this sector came to an end after insurance companies were opened up for private participation in the year 2000. Foreign players were allowed to enter into joint venture with their Indian counterpart with $26 \%$ holding and which was further increased to $49 \%$ in the year 2015 .

1.7.2 Economic factors. The gross savings of people in India have increased significantly thereby encouraging people to buy insurance policy to cover their risks. Insurance companies are fast becoming prominent players in the security market. As these companies have huge disposable income which they are investing in the security market.

1.7.3 Socio-cultural factors. Increase in insurance knowledge is helping people to increase their awareness about the risk to be covered through insurance. Change in lifestyle is leading to increase in risk thereby giving an opportunity to insurance companies to innovate newer products. Societal benefit is derived by transfer of risk through insurance due to improved socio-cultural environment.

1.7.4 Technological factors. Insurance companies deals in large database and maintaining it by the application of latest technology is huge gain for this sector. Technological advancement has helped insurance companies to sale their products through their electronic portals. This has made their task of providing service to the customers easier and faster.

\section{Review of literature}

After opening up of the insurance industry health insurance sector has become significant both from economic and social point of view and researchers have explored and probed these aspects.

Ellis et al. (2000) reviewed a variety of health insurance systems in India. It was revealed that there is a need for a competitive environment which can only happen with the opening up of the insurance sector. Aubu (2014) conducted a comparative study on public and private companies towards marketing of health insurance policies. Study revealed that private sector services evoked better response than that of public sector because of new strategies and 
technologies adopted by them. Nair (2019) has made a comparative study of the satisfaction level of health insurance claimants of public and private sector general insurance companies. It was revealed that majority of the respondents had claim of reimbursement nature through third party administrator. Satisfaction with respect to settlement of claim was found relatively higher for public sector than private sector. Devadasan et al. (2004) studied community health insurance to be an important intermediate step in the evolution of an equitable health financing mechanism in Europe and Japan. It was concluded that community health insurance programmes in India offer valuable lessons for its policy makers. Kumar (2009) examined the role of insurance in financing health care in India. It was found that insurance can be an important means of mobilizing resources, providing risk protection and health insurance facilities. But for this to happen, it will require systemic reforms of this sector from the end of the Government of India. Dror et al. (2006) studied about willingness among rural and poor persons in India to pay for their health insurance. Study revealed that insured persons were more willing to pay for their insurance than the uninsured persons. Jayaprakash (2007) examined to understand the hurdles preventing the people to purchase health insurance policies in the country and methods to reduce claims ratio in this sector. Yadav and Sudhakar (2017) studied personal factors influencing purchase decision of health insurance policies in India. It was found that factors such as awareness, tax benefit, financial security and risk coverage has significant influence on purchase decision of health insurance policy holders. Thomas (2017) examined health insurance in India from the perspective of consumer insights. It was found that consumers consider various aspects before choosing a health insurer like presence of a good hospital network, policy coverage and firm with wide product choice and responsive employees. Savita (2014) studied the reason for the decline of membership of micro health insurance in Karnataka. Major reason for this decline was lack of money, lack of clarity on the scheme and intra house-hold factors. However designing the scheme according to the need of the customer is the main challenge of the micro insurance sector. Shah (2017) analysed health insurance sector post liberalization in India. It was found that significant relationship exists between premiums collected and claims paid and demographic variables impacted policy holding status of the respondents. Binny and Gupta (2017) examined opportunities and challenges of health insurance in India. These opportunities are facilitating market players to expand their business and competitiveness in the market. But there are some structural problems faced by the companies such as high claim ratio and changing need of the customers which entails companies to innovate products for the satisfaction of the customers. Chatterjee et al. (2018) have studied health insurance sector in India. The premise of this paper was to study the current situation of the health-care insurance industry in India. It was observed that India is focusing more on short-term care of its citizens and must move from short-term to longterm care. Gambhir et al. (2019) studied out-patient coverage of private sector insurance in India. It was revealed that the share of the private health insurance companies has increased considerably, despite of the fact that health insurance is not a good deal. Chauhan (2019) examined medical underwriting and rating modalities in health insurance sector. It was revealed that while underwriting a health policy one has to keep in mind the various aspects of insured including lifestyle, occupation, health condition and habits. There have been substantial studies on health insurance done in India and abroad. But there has not been any work on performance of health insurance sector based on underwriting profit or loss.

\section{Research gap}

After extensive review of literature it is understood that there has not been substantial study on the performance of health insurance sector taking underwriting profit or loss into consideration. In spite of high rate of growth of earned premium, this sector is unable to 
$\mathrm{XJM}$

$17,1 / 2$

make underwriting profit. This is mainly because growth of premium is more than compensated by claims incurred and commission and other expenses paid. Thereby leading to growth of underwriting loss over the years across the different insurance companies covered under both public and private sector. This unique feature of negative performance of this sector has not been studied so far in India.

\section{Objectives}

The objective of this study has been to:

- review health insurance scenario in India; and

- study the performance of health insurance sector in India with respect to underwriting profit or loss by the application of regression analysis.

\section{Research methodology}

The study is based on secondary data sourced from the annual reports of Insurance Regulatory Development Authority (IRDA), various journals, research articles and websites. An attempt has been made to evaluate the performance of the health insurance sector in India. Appropriate research tools have been used as per the need and type of the study. The information so collected has been classified, tabulated and analysed as per the objectives of the study.

The data is based on a time period of 12 years ranging from 2006-2007 to 2018-2019.

Secondary data analysis has been done using regression of the form:

$$
\mathrm{Y}=\mathrm{a}+\mathrm{bX}
$$

The research has used SPSS statistics software package for carrying out regression and for the various graphs Microsoft Excel software has been used.

\subsection{The problem statement}

It is taken to be a general assumption that whenever the premium increases the profit also increases. This determines that profits are actually dependent on the premium income. Hence, whenever the premium tends to increase, the profit made also supposed to increase.

The aim of the study is to find out whether the underwriting profit of the health insurance sector is increasing or there is an underwriting loss.

The problem statement is resolved by applying regression analysis between the premium earned and underwriting profit or loss incurred. It is assumed that if the underwriting profit increases along with the premium received, then the pattern forms a normal distribution and alternate hypothesis can be accepted and if this pattern of dependability is not found then the null hypothesis will be accepted stating that there is no relation between the premium and the underwriting loss or the underwriting profit by the sector. But what is happening in this sector is the increase in premium is leading to increase in underwriting loss. So premium is negatively impacting underwriting profit which is astonishing thing to happen and is the crux of the problem of this sector.

5.1.1 Underwriting profit/loss $=$ net premium earned - (claim settled + commission and management expenses incurred). Underwriting profit is a term used in the insurance industry to indicate earned premium remaining after claims have been settled and commission and administrative expenses have been paid. It excludes income from 
investment earned on premium held by the company. It is the profit generated by the insurance company in the normal course of its business.

\subsection{Data analysis}

Table 1 shows that health insurance premium increased from Rs.1910 crores in 2006-2007 to Rs. 33011 crores in 2018-2019. But claims incurred together with commission and management expenses have grown from Rs. 3349 crores to Rs. 40076 crores during the same period. So the claims and management expenses incurred together is more than the health insurance premium earned in all the years of our study thereby leading to underwriting loss.

Claim incurred shown above is the outcome of the risk covered against which premium is received and commission and management expenses are incurred to obtain contract of insurance. Both these expenses are important for insurance companies to generate new business as stiff competition exists in this sector since it was opened up in the year 2000.

Figure 1 depicts the relationship between health insurance premium earned and claims and management expenses incurred by the insurance companies of the health insurance sector for the period 2006-2007 to 2018-2019.

Bar chart between premiums earned and claims and management expenses incurred show that claims and management expenses together is higher than premium earned in all the years of the study thereby leading to losses. Claims, commission and management expenses are important factors leading to the sale of insurance policies thereby earning revenue for the insurance companies in the form of premium. But proper management of claims and commission and management expenses will help this sector to improve its performance.

Table 2 provides insight into the performance of health insurance sector in India. The growth of health insurance in India has been from Rs.1909 crores for the financial year 2006-2007 to Rs. 33011crores for the financial year 2018-2019. The growth percentage is $1629 \%$ i.e. growing at an average rate of $135 \%$ per annum. Compounded Annual Growth Rate (CAGR) is working out to be $27 \%$.

From the same table, it can be inferred that health insurance sector is making underwriting loss in all the financial years. There is no specific trend can be seen, it has increased in some years and decreased in some other years. Here underwriting loss is

\begin{tabular}{lcccc}
\hline & $\begin{array}{c}\text { Health insurance } \\
\text { premium earned } \\
\text { (Rs. Crs.) }\end{array}$ & $\begin{array}{c}\text { Claims } \\
\text { incurred } \\
\text { (Rs. Crs.) }\end{array}$ & $\begin{array}{c}\text { Commission and } \\
\text { management exps } \\
\text { incurred (Rs. Crs.) }\end{array}$ & $\begin{array}{r}\text { Total claims and } \\
\text { commission and management } \\
\text { exps incurred (Rs.Crs.) }\end{array}$ \\
\hline 2006-2007 & 1909.59 & 2687.49 & 662 & 3349 \\
$2007-2008$ & 3224.27 & 3422.43 & 1139 & 4561 \\
$2008-2009$ & 5017.47 & 5256.19 & 1849 & 7105 \\
$2009-2010$ & 6351.82 & 6857.31 & 2362 & 9219 \\
$2010-2011$ & 8783.61 & 8546.18 & 3350 & 11896 \\
$2011-2012$ & 9660.52 & 9013.42 & 3239 & 12252 \\
$2012-2013$ & 11413.76 & 10834.29 & 3630 & 18174 \\
$2013-2014$ & 14373.7 & 14007.22 & 4167 & 22749 \\
$2014-2015$ & 17260.69 & 17405.79 & 5343 & 33148 \\
$2015-2016$ & 20456.57 & 20900.18 & 6629 & 34576 \\
$2016-2017$ & 24709.75 & 26088.59 & 7059 & 40076 \\
$2017-2018$ & 27875.24 & 26247.22 & 8329 & \\
$2018-2019$ & 33010.89 & 30027.26 & 10049 &
\end{tabular}

Source: Handbook on Indian Insurance Statistics. Website: www.irda.gov.in

Table 1.

Data showing health insurance premium earned and claims and management expenses paid 
$\mathrm{XJM}$

$17,1 / 2$

104

Figure 1.

Chart on health insurance premium earned and claims and management expenses paid

\section{Table 2.}

Data on performance of health insurance sector in India

\section{Data showing Health Insurance Premium earned \& Claims \& Management Exps. Incurred}

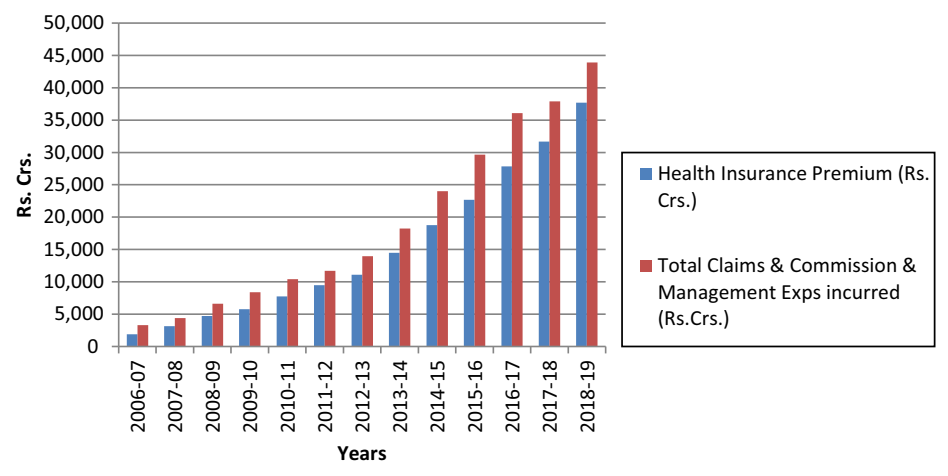

Source: Author's compilation

\begin{tabular}{lcccc}
\hline & $\begin{array}{c}\text { Net earned premium } \\
\text { of health insurance } \\
\text { (Rs. Crs.) }\end{array}$ & $\begin{array}{c}\text { Claims incurred } \\
\text { (Rs. Crs.) }\end{array}$ & $\begin{array}{c}\text { Commission and } \\
\text { management exps } \\
\text { incurred (Rs. Crs.) }\end{array}$ & $\begin{array}{c}\text { Underwriting } \\
\text { profit/loss (Rs. Crs.) }\end{array}$ \\
\hline $2006-2007$ & 1909.59 & 2687.49 & 662 & -1440 \\
$2007-2008$ & 3224.27 & 3422.43 & 1139 & -1337 \\
$2008-2009$ & 5017.47 & 5256.19 & 1849 & -2088 \\
$2009-2010$ & 6351.82 & 6857.31 & 2362 & -2867 \\
$2010-2011$ & 8783.61 & 8546.18 & 3350 & -2592 \\
$2011-2012$ & 9660.52 & 9013.42 & 3239 & -3051 \\
$2012-2013$ & 11413.76 & 10834.29 & 3630 & -3801 \\
$2013-2014$ & 14373.7 & 14007.22 & 4167 & -7073 \\
$2014-2015$ & 17260.69 & 17405.79 & 5343 & -8438 \\
$2015-2016$ & 20456.57 & 20900.18 & 6629 & -6701 \\
$2016-2017$ & 24709.75 & 26088.59 & 7059 & -7065 \\
$2017-2018$ & 27875.24 & 26247.22 & 8329 &
\end{tabular}

Source: Handbook on Indian Insurance Statistics. Website: www.irda.gov.in

calculated by deducting claims and commission and management expenses incurred from health insurance premium earned during these periods.

With every unit of increase in premium income the claims incurred together with commission and management expenses paid increased more than a unit. Thereby up setting the bottom line. So instead of earning profit due to better business through higher premium income, it has incurred losses.

Underwriting principles needs to be streamlined so that proper scrutiny of each policy is carried out so that performance of this sector improves.

It is seen from Figure 2 that there is stiff rise in premium earned over the years but claims and commission and management expenses incurred have also grown equally and together surpassed earned premium. So the net impact resulted in loss to this sector which can also 
Data showing Performance of Health Insurance Sector in India

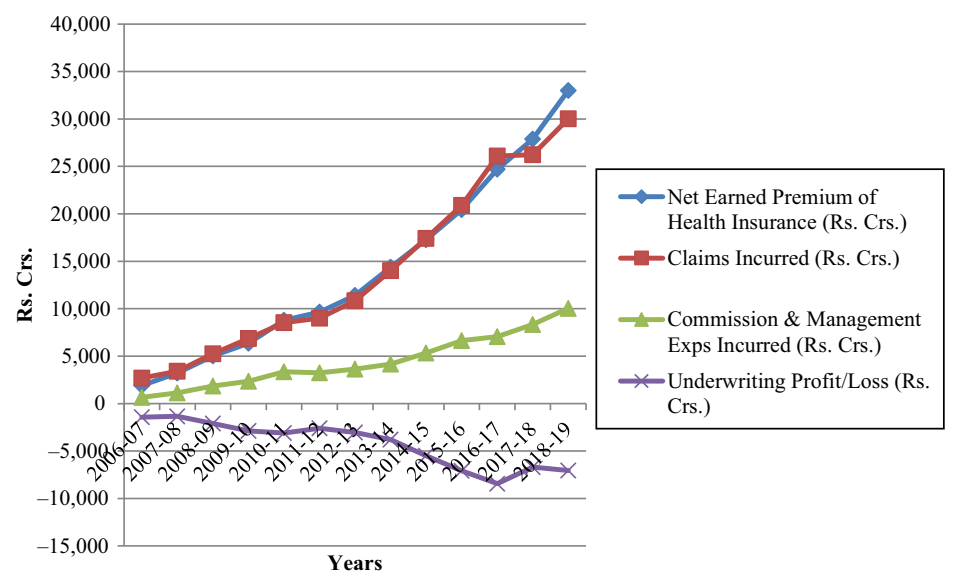

Source: Author's compilation

\section{Health insurance sector in India}

105
Figure 2.

Chart on performance of health insurance sector in India

be seen in the figure. It is also seen that loss is increasing over the years. So, increase in earnings of revenue in the form of premium is leading to increase in losses in this sector which is normally not seen in any other sectors.

But a time will come when commission and management expenses will stabilize through market forces to minimize underwriting losses. On the other hand, it will also require proper management of claims so that health insurance sector can come of this unprofitable period.

\subsection{Interpretation of regression analysis}

\subsubsection{Regression model.}

$$
\mathrm{Y}=\mathrm{a}+\mathrm{bX}
$$

Where

$$
\begin{aligned}
& \mathrm{Y}=\text { Dependent variable } \\
& \mathrm{X}=\text { Independent variable } \\
& \mathrm{a}=\text { Intercept of the line } \\
& \mathrm{b}=\text { Slope of the line }
\end{aligned}
$$

5.3.2 Regression fit. Here, Y is dependent variable (Underwriting Profit or Loss) which is to be predicted, $\mathrm{X}$ is the known independent variable (Health Insurance Premium earned) on which predictions are to be based and $\mathrm{a}$ and $\mathrm{b}$ are parameters, the value of which are to be determined (Table 3 ).

$$
\mathrm{Y}=-1028.737-0.226 \mathrm{X}
$$

5.3.3 Predictive ability of the model. The value of $R^{2}=0.866$ which explains $86.6 \%$ relationship between health insurance premium earned and loss made by this sector (Table 4). In other words, $13.4 \%$ of the total variation of the relationship has remained unexplained. 
$\mathrm{XJM}$

$17,1 / 2$

106

\subsection{H5.}

4.1 Regression coefficients (Table 5).

5.4.1.1 Null hypothesis. H1.1: $\beta=0$ (No influence of Health Insurance Premium earned on Underwriting Profit or Loss made)

5.4.1.2 Alternative hypothesis. H1.2: $\beta \neq 0$ (Health Insurance Premium earned influences underwriting Profit or Loss made by this sector)

The computed $p$-value at $95 \%$ confidence level is 0.000 which is less than 0.05 . This is the confidence with which the alternative hypothesis is accepted and the null hypothesis is rejected. Thus regression equation shows that there is influence of health insurance premium earned on loss incurred by this sector.

The outcome obtained in this analysis is not what happens normally in the industry. With the increase of revenue income in the form of premium, it may lead to either profit or loss. But what is happening surprisingly here is that increase of revenue income is leading to increase of losses. So growth of premium income instead of influencing profit is actually influencing growth of losses.

\section{Results}

\subsection{Findings}

The finding from the analysis is listed below:

The average growth of net premium for the health insurance has been around 135\% per annum even then this sector is unable to earn underwriting profit.

\begin{tabular}{lrr}
\hline Model & Unstandardized coefficients & Std. error \\
\hline 1 & & \\
(Constant) & -1028.737 & 458.900 \\
Premium earned & -0.226 & 0.027 \\
Note: a. Dependent variable: underwriting profit or loss & \\
\hline
\end{tabular}

Table 3.

Regression coefficients

\begin{tabular}{ccccc}
\hline Model & $R$ & $R$ Square & Adjusted $R$ square & Std. error of the estimate \\
\hline 1 & $0.930^{\text {a }}$ & 0.866 & 0.853 & 922.40531
\end{tabular}

Table 4.

Note: ${ }^{\text {a }}$. Predictors: (Constant), Health insurance premium earned

\begin{tabular}{|c|c|c|c|c|c|c|}
\hline & Model & Sum of squares & Df & Mean square & $\mathrm{F}$ & Sig. \\
\hline 1 & $\begin{array}{c}\text { Regression } \\
\text { Residual } \\
\text { Total }\end{array}$ & $\begin{array}{c}60260377.756 \\
9359147.167 \\
69619524.923\end{array}$ & $\begin{array}{c}1 \\
11 \\
12\end{array}$ & $\begin{array}{c}60260377.756 \\
850831.561\end{array}$ & 70.825 & $0.000^{\mathrm{b}}$ \\
\hline
\end{tabular}

Table 5. ANOVA
Notes: ${ }^{a}$. Dependent variable: Underwriting profit or loss; ${ }^{\mathrm{b}}$. Predictors: (Constant), Health insurance premium earned 
The CAGR works out to around $27 \%$. CAGR of $27 \%$ for insurance sector is considered to be very good rate of growth by any standard.

Along with high growth of premium, claims and commission and management expenses incurred in this sector have also grown substantially and together it surpassed in all the years of the study.

Thus, growth of claims and commission and management expenses incurred has more than compensated high rate of growth of health insurance premium earned. This resulted into underwriting loss that this sector is consistently making.

Astonishing findings has been higher rate of increase of premium earnings leading to higher rate of underwriting loss incurred over the years. Even though the sector is showing promise in terms of its revenue collection, but it is not enough to earn underwriting profit.

\subsection{Recommendations}

COVID 19 outbreak in India has led to a spike in health-care costs in the country. So, upward revision of premium charges must be considered to see bottom line improvement in this sector.

Immediate investigation of the claim is required. This will enable the insurers to curb unfair practice and dishonest means of making a claim which is rampant in this sector.

Health insurance market is not able to attract younger generation of the society. So entry age-based pricing might attract this group of customers. An individual insured at the age 30 and after 10 years of continuous coverage the premium will be less than the other individual buying a policy at the age of 40 for the first time.

\subsection{Limitations and scope of future studies}

The analysis of performance of health insurance sector in India taking underwriting profit into consideration is the only study of its kind in this sector. As a result, adequate literature on the subject was not available.

Health insurance and health care are part of medical care industry and are inter dependent with each other. So performance of health insurance sector can be better understood by taking health-care industry into consideration which is beyond the scope of the study.

This sector is consistently incurring losses. So, new ideas need to be incorporated to reduce losses if not making profits.

Opportunity of the insurance companies in this sector lies in establishing innovative product, services and distribution channels. So, continuous modification by the application of research is required to be undertaken.

Health insurance sector will take a massive hit, as tax benefit is going to be optional from this financial year. This can be a subject of study for the future.

\subsection{Conclusion}

This sector is prone to claims and its bottom line is always under tremendous pressure. In recent times, IRDA has taken bold step by increasing the premium rate of health insurance products. This will help in the growth of this sector.

With better technological expertise coming in from the foreign partners and involvement by the IRDA the health insurance sector in India must turn around and start to earn profit.

The COVID-19 pandemic is a challenge for the health insurance industry on various fronts at the same time it provides an opportunity to the insurers to fetch in new customers. 
The main reason for high commission and management expense being cut-throat competition brought in after opening up of the insurance sector in the year 2000. So, new companies are offering higher incentives to the agents and brokers to penetrate into the market. This trend needs to be arrested as indirectly it is affecting profitability of this sector.

The study will richly contribute to the existing literature and help insurance companies

\section{References}

Aubu, R. (2014), "Marketing of health insurance policies: a comparative study on public and private insurance companies in Chennai city", UGC Thesis, Shodgganga.inflibnet.ac.in.

Chatterjee, S., Giri, A. and Bandyopadhyay, S.N. (2018), "Health insurance sector in India: a study", Tech Vistas, Vol. 1, pp. 105-115.

Chauhan, V. (2019), "Medical underwriting and rating modalities in health insurance", The Journal of Inssurance Institute of India, Vol. VI, pp. 14-18.

Devadasan, N., Ranson, K., Damme, W.V. and Criel, B. (2004), "Community health insurance in India: an overview”, Health Policy, Vol. 29 No. 2, pp. 133-172.

Dror, D.M., Radermacher, R. and Koren, R. (2006), "Willingness to pay for health insurance among rural and poor persons: Field evidence form seven micro health insurance units in India", Health Policy, pp. 1-16.

Ellis, R.P., Alam, M. and Gupta, I. (2000), "Health insurance in India: Prognosis and prospectus", Economic and Political Weekly, Vol. 35 No. 4, pp. 207-217.

Gambhir, R.S., Malhi, R., Khosla, S., Singh, R., Bhardwaj, A. and Kumar, M. (2019), "Out-patient coverage: Private sector insurance in India”, Journal of Family Medicine and Primary Care, Vol. 8 No. 3, pp. 788-792.

Gupta, D. and Gupta, M.B. (2017), "Health insurance in India-Opportunities and challenges", International Journal of Latest Technology in Engineering, Management and Applied Science, Vol. 6, pp. $36-43$.

Hand book on India Insurance Statistics revisited (2020), "Insurance regulatory and development authority website", available at: www.irda.gov.in (accessed 2 July 2020).

Jayaprakash, S. (2007), "An explorative study on health insurance industry in India”, UGC Thesis, Shodgganga.inflibnet.ac.in.

Kumar, A. (2009), "Health insurance in India: is it the way forward?”, World Health Statistics (WHO), pp. 1-25.

Nair, S. (2019), "A comparative study of the satisfaction level of health insurance claimants of public and private sector general insurance companies", The Journal of Insurance Institute of India), Vol. VI, pp. 33-42.

Savita (2014), "A qualitative analysis of declining membership in micro health insurance in Karmataka”, SIES Journal of Management, Vol. 10, pp. 12-21.

Shah, A.Y.C. (2017), "Analysis of health insurance sector post liberalisation in India", UGC Thesis, Shodgganga.inflibnet.ac.in.

Thomas, K.T. (2017), "Health insurance in India: a study on consumer insight”, IRDAI Journal, Vol. XV, pp. 25-31.

Yadav, S.C. and Sudhakar, A. (2017), "Personal factors influencing purchase decision making: a study of health insurance sector in India”, BIMAQUEST, Vol. 17, pp. 48-59.

\section{Further reading}

Beri, G.C. (2010), Marketing Research, TATA McGraw Hill Education Private, New Delhi, ND. 
Dutta, M.M. and Mitra, G. (2017), "Performance of Indian automobile insurance sector", KINDLER, Vol. 17, pp. 160-168.

Majumdar, P.I. and Diwan, M.G. (2001), Principals of Insurance, Insurance Institute of India, Mumbai, MM.

Pai, V.A. and Diwan, M.G. (2001), "Practice of general insurance", Insurance Institute of India, Mumbai, MM.

Shahi, A.K. and Gill, H.S. (2013), "Origin, growth, pattern and trends: a study of Indian health insurance sector", IOSR Journal of Humanities and Social Science, Vol. 12, pp. 1-9.

\section{Corresponding author}

Madan Mohan Dutta can be contacted at: mmd_248@yahoo.co.in

For instructions on how to order reprints of this article, please visit our website: www.emeraldgrouppublishing.com/licensing/reprints.htm Or contact us for further details: permissions@emeraldinsight.com 